\title{
XI. ve XII. Yüzyıllarda Akka'da İdari, Sosyal ve İktisadî Hayat ${ }^{1}$ \\ Administrative, Social and Economic Life in Acre from 11th through 12th Centuries
}

\section{Dr. Mustafa Yıldırım²}

Başvuru Tarihi: 06.11.2019

Kabul Tarihi: 23.06.2020

Makale Türü: Araştırma Makalesi

Öz

Yüzyıllar boyunca Akad, Babil, Fenike, Roma İmparatorluğu, Emeviler, Abbasiler gibi devletlerin hâkimiyeti altına giren Akka, XI. yüzyıla kadar idarî, sosyal ve iktisadî yönden farklılıklar göstermiştir. X. yüzyılın sonundan itibaren Fâtımiler dönemiyle birlikte ilk kez Şî̂ Müslüman bir devletin hâkimiyeti altına giren şehir, 1074 yılında Selçukluların hâkimiyetine girmiş ve Haçlı Seferleriyle birlikte iki asır boyunca Haçlıların hâkimiyeti altında kalmıştır. Akka, Kudüs'ün Selahaddin Eyyûbi tarafından fethedilmesiyle birlikte Kudüs Krallı̆̆ı'nın başkenti olmuş ve Memlûk Devleti'nin bölge topraklarını 1291'de fethetmesine kadar bu özelliğini sürdürmüştür. İslam fetihlerinden önce Yahudi ve Hristiyanların, İslam fetihleriyle birlikte Müslümanların bölge topraklarına gelmesi, şehrin etnik ve sosyal yönden değişiklik göstermesine katkıda bulunmuştur. Nitekim İslamiyetin ilk yayılma sahalarından biri, bölge toprakları olduğundan ve üç semavi dinin kutsal şehri Kudüs'e yakın olmasından dolayı Akka, dini bakımdan da önemini sürekli korumuştur. Ekonomik bakımdan ise şehir, Orta Doğu gibi yüzyıllar boyunca stratejik bakımdan önemli bir coğrafyada bulunması ve sahil şeridinde yer alması nedeniyle şehirde deniz yoluyla yapılan ticari faaliyetlerin yapılması mümkün olmuştur. Neticede bu çalışmada XI. ve XII. yüzyıllarda Akka'nın idari bakımdan kimler tarafından yönetildiği, sosyal bakımdan şehrin sahip olduğu özellikler ve yapılan ekonomik faaliyetler anlatılmaya çalışılmıştır.

Anahtar Kelimeler: Akka, Şehir, İdare, Hâkimiyet, Ekonomi

\section{Abstract}

Having been ruled by such civilizations as Phoenicians, Babylonia, the Roman Empire, Umayyad, and Abbasids for centuries, the city of Acre showed differences in terms of administrative, social and economic affairs up until the $11^{\text {th }}$ century. Beginning with its conquest by the Fatimid Empire, this city came under the rule of a state ruled by Shi'ite Muslims towards the end of the $10^{\text {th }}$ century. It was conquered by the Seljuk Empire in 1074 but remained under the Crusade's power for two

\footnotetext{
${ }^{1}$ Bu makale doktora tezinden üretilmiştir. Yıldırım, Mustafa, "XI. ve XII. Yüzyıllarda Akka Şehri”, Basılmamış Doktora Tezi, Ankara Üniversitesi Sosyal Bilimler Enstitüsü, Ankara, 2020.

2 Ankara Üniversitesi, Sosyal Bilimler Enstitüsü Mezunu, myildirimbjk@gmail.com, ORCID 0000-0002-2560-9758
} 
centuries following the Crusades. However, upon being conquered by The Ayyubids under Sultan Salahuddin Ayyubi, it earned the status of the capital city of the Jeruselam Kingdom, which continued until it was conquered by the Mamluk Sultanate. Not only invasions of the city by Jews and Christians but also Islamic conquests contributed a great deal to the transformation of the ethnic and social structures of Acre. Being one of the earliest territories where Islam spread, this city maintained its religion-based significance for a very long time considering its closeness to Jeruselam, which is viewed as sacred in all the three monotheistic religions. As to its significance for the economy, Acre is located along the seashore of a strategically important geography like the Middle East, where various marine trades have been carried out through business operations for centuries. The present study has the purpose of discussing who the city of Acre was administered by, from the $11^{\text {th }}$ to $12^{\text {th }}$, apart from its social characteristics and economic operations conducted there.

Keywords: Acre, City, Administration, Sovereignty, Economy

\section{Giriş}

Akka, XI. yüzylla kadar içinde bulunduğu Filistin topraklarına sahip olan devletlerin çeşitli idari yönetimlerine şahit olmuştur. Tarih boyunca Mısır, Akad, Asur, Babil, Makedon, Roma, Bizans, Emevîler, Abbasîler ve Selçukluların hâkimiyetinde kalmıştır. Filistin'in şehirleri, M.Ö. XV. yüzyılda, Mısır'ın bölgedeki genel valileri tarafından yönetilmiştir. Suriye ve Filistin bölgeleri "amelu" ünvanlı prenslerin idaresinde iken daha sonra "hazzanu" ünvanlı genel valiler tarafından idare edilmiştir. M.Ö. XIII. yüzyılda Hitit İmparatorluğu'nun dağılma sürecinde olmasından ve Mısır İmparatorluğu'nun da zayıflayarak Ürdün, Filistin ve Suriye bölgesinde hâkimiyetini kaybetmesinden dolayı Filistin bölgesindeki şehirlerde bağımsız şehir krallıkları kurulmuştur. Hiksosların Mısır'dan kovulmasının ardından ise Filistin artık Mısır'ın bir ili olmuştur. Hiksoslar zamanında Filistin bölgesinde bir çeşit feodalite yönetimi hâkim olduğundan Mısırlılar da onları bölgeden çıkarmalarının ardından bu yönetim şeklini sürdürmeye devam etmişlerdir Mısır'ın buradaki yönetim merkezleri Gazze ve Yafa şehirleri olmuştur. (Gül, 1997, s. 176-177).

M.Ö. XI. yüzyllarda Kudüs merkezli Yehuda Devleti kurulmuş ve içinde Akka'nın da bulunduğu Filistin'in diğer şehirlerini ele geçirmiş̧tir. M.Ö. 735’te Asur ve M.Ö. 530'da Pers hâkimiyetine giren Filistin, İran’a bağlanmıştır Büyük İskender, bölgeyi ele geçirdiğinde Filistin ve Suriye'de "komün" idaresi bulunmaktaydı. Büyük İskender'den sonra bölgedeki şehirler Seleukoslara bağlı olarak yönetilmiştir. Roma İmparatorluğu döneminde ise bu şehirler Roma kolonileri olarak yeniden teşkilatlandırılırken Filistin'in merkezi de Kayserya olmuştur (Gül, 1997, s. 178). 
Bölge, Müslümanlar tarafından fethedildikten sonra Hz. Ebubekir ve Hz. Ömer dönemlerinde atanan valiler tarafından yönetilmiştir. VIII. yüzyıldan itibaren ise Remle şehri Filistin'in idari merkezi ve başkenti olmuştur. (Strange, 1890, s. 84). Böylece Akka, İslam fetihlerinden sonra Filistin'de merkezi konumunu kaybetmiştir. Akka, Tolunoğulları ve İhşîdiler hâkimiyetine girdiğinde ise amiller tarafından idare edilmiştir (Köprülü, 1997, s. 402-403).

Çalışmamızda XI. ve XII. yüzyıllarda Akka'nın idarî yapısı incelenirken ilk önce bölgeye hâkim olan devletler ve daha sonra bu devletlerin bölgeyi yönetim şekilleri, sosyal ve iktisadî yapıları incelenecektir. Söz konusu dönemde bölgeye hâkim olan devletler şunlardır; Fâtımîler (9701074 ve 1087-1204), Selçuklular (1074-1087), Kudüs Krallığı (1104-1187 ve 1191-1291) ve Eyyûbîler (1187-1191). Anlaşılacağı üzere Selçuklular ve Eyyûbîler bölge topraklarına çok kısa süre hâkim olduklarından dolayı bölgede tam olarak iktidarı sağlayamamışlardır.

\section{a) Akka'nın İdarî ve Sosyal Yapısı:}

\section{1) Fâtımîler ve Selçuklular Döneminde İdari ve Sosyal Yapı:}

Fâtımîlerde, El-İmam, Emir-ül Mü'min'in gibi lakaplar kullanan halife, Allah'ın yeryüzündeki temsilcisi kabul edilirdi. Halifelik, tıpkı Abbasilerde olduğu gibi babadan oğula geçerdi. Devlet halife ailesinin mülkü sayılıyordu. Bu yüzden devletin hâkim olduğu bütün topraklar, Halife'ye ait olup eğer ki halife ölürse en büyük oğluna bu miras kalıordu (Yılmaz, 2016, s. 19). Halifeliğin merkezi Mısır fethedildikten sonra Kahire olmuştur. Vilayetlerde ise görev vali veya emire (amil) ya da sahibü'l-harac denilen yüksek seviyedeki kişiye tevdi edilirdi. Fâtımîler, fethettikleri bölgeleri bölge valilikleri sistemi ile yönetmiştir (Hasan, 1985, s. 179). Bedrü’lCemâli, Akka Valiliği yapmış en meşhur ve en önemli Fâtımî devlet adamlarındandır (Özaydın, 1992, s. 330). Selçukluların Akka'yı fethettiği dönemde ise Bedrü'l-Cemâli'nin adına İbn Sukha tarafından yönetiliyordu (Sevim, 2000, s. 66). Valilerin yanında şehirlerde devlet işlerinin yürütülmesi için onlara yardımcı olan başka memurluklarda bulunmaktaydı. Akka'da da bulunan bu memurlukları şu şekilde sıralamak mümkündür: a) Kadı, b) Bündar, c) Sahibü’lCünd (Divan), d) Sahibü'l-Berid (Hasan, 1985, s. 198).

a) Kadı:"القاضي" (Kzy) kökünden gelen ve fiilin masdarı olan kaza, hüküm, karar ve hâkimlik anlamlarına gelmektedir. Kadı, işi yapan anlamında hâkim anlamına gelmektedir. Görevi, insanlar arasındaki anlaşmazlıklar çözmektir. İslam tarihinde ilk kadılık müessesesi, Hz. Ömer döneminde kazalara kadıların atanmasıyla ortaya çıkmıştır. Abbâsiler döneminde ise ayrıca kadı'l-kudatlık müessesesi kurulmuştur. İslâm devletlerinde şehirlerdeki kadıların ataması başkentten yapılırdı (Mardin, 1997, s. 42; Zeydan, 1965, s. 236; Gül, 1997, s. 204).

b) Bündar: Ticari eşya ve vergiler ile ilgilenen devletin görevlendirdiği kişidir (Hasan, 1985, s. 198).

c) Sahibü’l Cünd (Divan): İslâm dünyasında, ilk defa Hz. Ömer'in fey ${ }^{3}$ gelirlerini dağıtmak için kurduğu divan teşkilâtıyla birlikte yaygın bir şekilde kullanılmaya başlanan divan tabiri

${ }^{3}$ Fey sözlükte masdar olarak "geri dönmek, şekil değiştirmek”, isim olarak "gölge, öğle vaktinden sonraki gölge” anlamlarına gelir. Terim olarak gayri müslimlerden alınan haraç, cizye, ticarî mal vergisi (ușûr) ve diğer bazı gelirleri ifade eder. Fey hakkında detaylı bilgi için bkz. Fayda, 
Emevîler ve bilhassa Abbâsîler zamanında, başta askerî ve malî sahalar olmak üzere çeşitli devlet hizmetlerine bakan müesseselere isim olarak verilmiştir. Fâtımî divanları aslında Abbâsî divanları ile benzerlik arzeder. Dîvânü'r-resâil burada Dîvânü'l-inşâ olmuştur. Başında sâhibü'd-dîvâni'l-inşâ bulunurdu. Dîvânü'l-cünd, Dîvânü'l-ceyş olarak adlandırılmıştı. Askerlerin orduya alınması, teçhizatı ve denetimiyle ilgilenen müstevfî yönetimindeki Dîvânü'l-ceyş ve ödemelerle ilgilenen Dîvânü’r-revâtib olarak iki bölümden meydana geliyordu. Bununla beraber bazı bilgiler bu iki divanın sık sık ayrıldığını, ilkinin sâhib'ü-dîvânü'l-ceyşin yönetiminde olduğunu, ikincisinin de asker ve sivil maaşlarıyla ilgilendiğini göstermektedir. Donanmaya büyük önem veren Fâtımîler'de gemi yapımı ve deniz kuvvetlerine bakan Dîvânü'l-amâir vardı. Maliye ile ilgilenen divanların işleri karışıktı. Görünüşe göre Dîvânü’l-meclis merkezî büro idi. Bir bölümünün iktâlarla ilgilendiği bilinen bu divanın değişik bölümleri vardı (Abdülaziz ed-Dûri, 1994, s. 377-381). Bunların yanı sıra Fâtımîlerde Dımaşk'da bulunan Divanü'ş-Şam da Suriye ve Filistin bölgesindeki şehirlerin işlerini yürütmekle görevli divandı (Hasan, 1985, s. 208). Akka'da bu bölgedeki şehirlerden birisi olup yönetim bakımından Divanü’ş-Şam’a bağlıydı.

d) Sahibü'l-Berid: Berîd kelimesi "süvari, postacı, elçi, ulak, iki posta menzili arasındaki mesafe, postaya verilen yazılar ve dosyalar, resmî işlerle ilgili posta" gibi çeşitli mânalarda kullanılmıştır. İslâm tarihinde resmî postanın düzenlenmesi çalışmaları daha $\mathrm{Hz}$. Peygamber zamanında başlamıştır. Nitekim bu devirde yazışma, talimat ve anlaşma metinleri özel elçiler vasıtasıyla gönderilmekteydi. Posta taşımacılığında şartlara göre deve, at ve katır kullanılmıştır. Bunun yanı sıra Fâtımîlerde, posta güvercinleri de haberleşmek için kullanıldığından posta güvercinleri için divan kurulmuştur. Suriye, Filistin ve Misır arasındaki haberleşme bu şekilde yapılmıştır (Harekât, 1992, s. 498-501).

Fâtımî ordusu ise Rumlar ve Sicilyalılardan oluşmaktaydı. Fâtımîlerin Selçuklulara kaybettikleri savaştan sonra Türklerin Fâtımî ordusunun omurgasını oluşturduğunu söylenebilir (Yılmaz, 2016, s. 25). Fâtımîler döneminde askeri kuvvetler, Akka'ya başkentten atanan valinin kuvvetleri ile sinırlıdır.

Filistin bölgesi, 1069 ve 1070 yıllarında buraya gelen Navakiyye Türkmenlerinin istilasına uğramış ve Kurlu Bey’in idaresinde başkent Remle olmak üzere ilk Türkmen Beyliği kurulmuştur. Kurlu Bey’in ölümünden sonra Atsız, Kudüs'ü başkent yaparak Türkmen Beyliği'ni Selçuklu Melikliği'ne çevirmiştir. Selçukluların 1074 yılında Akka'yı fethetmesiyle başlayan süreçte ise komutan Şöklü ile Atsız arasında anlaşmazlıklar çıkmıştır. Atsız, Şöklü’yü öldürdükten sonra içinde Akka'nın da olduğu Filistin şehirlerini Selçuklu Melikliği’ne dâhil etmiştir. Atsız, Dımaşk’ı fethettikten sonra başkenti de buraya taşımıştır. Sultan Melikşah,

M. (1995), “Fey”, (C.XII, s.511-513), İstanbul; TDV İslam Ansiklopedisi. Hz. Ömer Irak, İran, Cezîre, Suriye, Filistin ve Misır’n fethiyle birlikte İslâm devleti hâkimiyeti altına giren gayri müslimlerin verdikleri ve fey adı altında toplanan cizye, haraç ve ticaret malları vergileri sonucunda artan gelirleri müslümanlara dağıtmak üzere bir teşkilât düşünmüştü. Kaynaklarda 636 yllı zikredilmekle birlikte güvenilir otoritelerin 641 tarihinde kurulduğunu ifade ettikleri divan teşkilâtı muharip güçleri kaydetmek ve hazineyi düzene koymak için teşekkül etmişti. Bu ilk divana bazıları Dîvânü'l-cünd adını vermişlerse de bunu yalnızca divan diye adlandıranlar çoğunluktadır. Dîvânü'l-cünd, rütbelerine göre tasnif edilmiş askerî kıtalar ve onların ödeme veya iktâlarının kayıtlarını tutardı. Bu divan biri ödeme ve harcamalarla ilgilenen, diğeri de asker alımları ve sınıflandırma yapan iki bölümden meydana gelmekteydi. Divanın hesap ve harcamalarına Zimâmü'lceyş adlı bir divan nezaret ediyordu. Divanın İslam tarihindeki yeri hakkında detaylı bilgi için bkz. Abdülaziz ed-Dûrî, (1994), "Divan", (C.IX, s.377-381) İstanbul: TDV İslam Ansiklopedisi. 
Atsız'in Sur, Sayda ve Trablusşam gibi şehirleri fethettikten sonra kurduğu Selçuklu Melikliğine, veziri Nizamülmülk'ün uygun bulmamasına rağmen Atsız'ı görevden alıp yerine Melik olarak kardeşi Tacüddevle Tutuş'u atamıştır.(Sevim, 2000, s. 72-84).

\section{2) Kudüs Haçlı Krallığı ve Eyyûbiler Döneminde İdari ve Sosyal Yapı:}

I. Haçlı Seferinden hemen sonra ele geçirilen ve Hristiyanlar için kutsal kabul edilen topraklar, Kral Godefroi'ye sadık kişiler arasında paylaştırılarak. Krallıkta sayısız lordlar oluşturulmuştur. Bu lordların sayısı XII. ve XIII. yüzyıllarda sürekli değişse de Haçlıların ele geçirdiği şehirler Kudüs Krallı̆̆ı'nın bir parçasıdır (Murray, 1997, s. 301). Kudüs Krallığı'nda tahta geçme usulleri klan mücadeleleri, yabancıların nüfuzları ve yüksek dereceli bazı feodallerin güçlerine göre şekillenmekteydi (Cahen, 2010, s. 217-218). Kral ve kraliyet mahkemesi, asıl Kudüs'te bulunsa da Kudüs'ün küçük, nüfusunun az olması ve Müslümanların Kudüs'e alınmamasından dolayı aynı sıklıkta Akka, Nablus, Sur ve diğer şehirlerde de toplanmaktaydı. Kraliyet ailesi, ülkeyi Kudüs'te Tapınak Şövalyeleri ${ }^{4}$ tarikatının kurulmasından önce Tapınak Dağı'nda daha sonra da Davut Kulesi'ni çevreleyen saray kompleksinden yönetmekteydi. Ayrıca Akka'da da kralıngeldiğinde kaldığı başka bir saray kompleksi de mevcuttu (Murray, 1997, s. 301). Hittîn savaşıyla Kudüs'ün Müslümanlar tarafından ele geçirilmesinin ardından Kudüs Krallı̆̆g’nın başkenti 1191'de Kudüs'ten Akka’ya taşınmıştır.

Haçlı seferleri ile birlikte Avrupa'dan gelen soylular, piskoposlarla birlikte yeni kralın seçilmesini onaylamak, vergi toplamak, madeni para basmak ve krala para toplamak işlerinden sorumlu olan yüksek mahkemeyi (Hight Court) oluşturmuşlardır. Kudüs Krallığının ilk yasaları ise geleneklere göre 1120'de Nablus Konsül'ünde II. Baldwin tarafından konulmuştur (Nader, 2006, s. 45). Soylu sınıfından olmayan ve Latin olmayanlar için ise Kudüs Krallığında ayrı ayrı mahkemeler bulunmaktaydı. Bunlar nispeten daha küçüktü. Burjuva Mahkemesi (Court of the Bourgeois), soylu olmayan Latinlerin aralarındaki anlaşmazlıkları çözmekle ve hırsızlık saldırı gibi konularla ilgilenirdi. Yafa, Kayserya, Akka ve Hayfa gibi kıyı şehirlerinde ise Ticaret Mahkemeleri (Court of The Fund) ve Deniz Mahkemeleri (Court of The Maritime) gibi özel mahkemeler bulunmaktaydı (Kedar, 1999, s. 310; Nader, 2006, s. 158-170).

Eyyûbîler döneminde ise Akka, çok kısa bir süre Eyyûbîlerin hâkimiyetinde kalmıştır. Hittîn savaşının kazanılmasıyla birlikte Kudüs'te dâhil olmak üzere Selahaddin Eyyûbî birçok şehri ele geçirmişti. Bu şehirlerarasında Taberiye, Akka, Safûriye, Remle, Kartiye, Sûbe gibi şehirler vardı. Selahaddin Eyyûbî 9 Temmuz 1187 yılında Akka'yı fethederek şehrin idaresini oğlu elEfdal'e bırakmıştır. Ancak çok kısa bir zaman sonra III. Haçlı Seferleriyle birlikte Akka kaybedilmiştir (Şeşen, 1987, s. 117-122).

Akka Orta Doğu gibi bir coğrafyada bulunduğundan nüfusu her asırda farklı milletlerden oluşmaktadır. Savaşlar ve mücadeleler bu nüfus yapısını sürekli etkilemiştir. Fâtımîler

\footnotetext{
${ }^{4}$ Amaçları, Kudüs'ü ziyaret edecek Hristiyanları korumak ve onların yol güvenliğini sağlamak olan dokuz kişilik gruplardan oluşan Tapınak Şövalyeleri, Fransız Hugues de Paynes liderliğinde Geoffroy de Saint-Omer, André de Mantbard, Payen de Montdidier, Archambaud de Saint-Aignan, Geoffroy Bisol, Hughes Rigaud, Rossal ve Gondemare tarafından 1118 yılında Fransa'da olușturulmuștur. İlk büyük üstatları, Hugues de Paynes'tir. Ayrıntılı bilgi için bkz. Kocabaş, H. Masonluğun Kurucuları: Tapınak Şövalyeleri https://www.hasankocabas.com.tr/icerik-462-tapinak_sovalyeleri_ve_masonluk.html (E.T.16.06.2020)
} 
dönemiyle Şî̂ nüfusunun yoğunlaşmaya başladığı yer olan Akka, Şiîliğin yanısıra Müslümanlığın diğer mezhebi Sünniliğinde yaşandığı bir şehirdi. Haçlı seferleri ile birlikte Avrupa'nın değişik milletlerinden Latinler bölgeye gelerek Akka’nın Hristiyan nüfusunu teşkil etmiştir (Hazard, 1977, s. 4-5).

I. Haçlı Seferinin ardından Filistin bölgesi kimisi kutsal topraklar uğruna savaşmak için gelen kimisi de yeni bir hayat kurmaya gelen yerleşimcilerin akınına uğramıştır. Bu yeni gelenler karşılarında Müslümanlardan, Dürzîlerden, Yahudilerden, Samirilerden oluşan gruplar buldular. Haçlı Krallığı zamanında Filistin'deki Hristiyan nüfusun büyüklüğünü tahmin etmek zordur. Kudüs Krallığında kilise hiyerarşisi Katolik Latinlerin kontrolündeydi. Buna rağmen bazı bölgelerde Ortodoks piskoposlarının halkın başında olduğu da görülür. Mesela 1173’te Gazze ve Beyt Cibrin'deki Yunan başpiskoposu Ortodoks bölgesinde yetkili olmuştur. Ermenilerin Kudüs'te ayrı katedralleri olduğu gibi Yakubilerin de hem Kudüs'te hem de Akka'da katedralleri vardı. Bu katedrallerin sayısı nüfusun büyüklüğüne ve küçüklüğüne göre Filistin'in genelinde değişiyordu. Kudüs Krallığında yerleşim yerine göre bir kilise bulunurdu. Nüfusun artmasına bağlı olarak yeni kiliseler inşa edilmiştir. Akka'da birden fazla kilise bölgesinin varllğı mevcuttur (Pringle, 2002, s. 102-106).

Kudüs Krallığında kiliselerin yanı sıra manastırlar da bulunurdu. Manastırların bulundukları şehirler; Sina Dağı, Taber Dağı, Karmel Dağı, Tell Yunus, Beyrut, Beyt Cibrin, Akka ve Sur idi Manastırlar ve kırsal bölgelerdeki kiliselerin en yoğun olduğu yerler Kudüs ve Lut iken seyrek olduğu yerler ise Akka, Taberiye, Kayserya ve Nazaret'tir. XII. yüzyllda Akka'da bulunan kilise sayısı yirmi yedidir (Pringle, 2002, s. 111).

\section{b) Akka'nın iktisadi Yapısı:}

\section{1) Fâtımîler Döneminde íktisadî Yapı:}

Fâtımîler Döneminde Kahire şehri, ülkenin ticaret, eğitim, sanat ve mimari gibi alanlarında merkezi konumdaydı. Fatımilerin Kahire ile kıyllarda söz sahibi olmasıyla birlikte İskenderiye de ticaretin merkezi olmuştur. Avrupa'dan ve Anadolu'dan gelen mallar, ilk önce İskenderiye'ye ulaşır oradan da ülkenin iç kısımlarına dağılırdı. Bu mallar, bazen Dimyat ve Tinnîs'e kadar ulaşırdı. Ticaretin canlı olması nedeniyle Kahire, tüccarlar için bir cazibe merkezi olmuştur. XI. yüzyılda Kızıldeniz'den ve İskenderiye'den getirilen mallar Küs şehrinden geçerek Kahire’ye ulaştırılırdı. Bu sebeple Kahire'de tüccar bayileri kurulmuştur (Yılmaz, 2016, s. 28-29). Müslüman ve Hristiyan hacıların yol güzergâhı olmasından dolayı o dönemde ticaret daha çok Dımaşk ve Kudüs endeksli idi. Dımaşk, önemli yolların kesişme noktasında olduğundan kuzeyden gelen Müslüman hacılar Dımaşk'da birleşiyor ve Mekke'ye kadar beraber yolculuk yapıyorlardı. Kudüs'te de Müslüman hacılar Hristiyanlarla karşılaşıp onlarla ticaret yapıyorlardı. Süregelen bu hareketlilik Dımaşk ve Kudüs bölgesine birçok eşyanın ve erzakın girmesine neden oluyordu. Cerablus, Beyrut, Sur ve Akka limanları Dımaşk ile Kudüs'e birkaç günlük uzaklıkta bulundukları için Ortaçağ’da insanlar bu limanlar aracıllyla kolaylıkla ihtiyaçlarını karşılıyorlardı (Heyd, 1975, s. 48). Bölgede ticaret, panayırlara dayanıyordu. Her grup tacir, bu panayırlarda bir bölüm açar ve akşam olmadan evlerine dönmezlerdi. Mısır, Suriye ve Filistin'in şehirlerindeki dükkânlar, caddelerin iki yakası boyunca uzanırdı. Şehirlere 
dışarıdan gelen tüccarlara tahsis edilen hanlar, büyük çarşılara benzerdi. Bu tüccarlar, hanlarının alt katlarına ticaret eşyalarını koyarlar ve üst katlarında da yatarlardı. Odalarını rum kilitleriyle kilitlerlerdi. Bu çarşı ve depolara "el-Fenadik veya el-Kayasır" denirdi (Hasan, 1985, s. 269). Söz konusu dönemde Akka’nın ekonomik olarak canlı olması, Kudüs ve Dımaşk'ın bu hareketliliğine bağlı kalmıştır.

Fâtımîler, ithal ve ihraç mallarına konulan gümrük vergisinden büyük gelir elde etmişlerdir. Herhangi bir ticaret gemisi, devletin liman şehirlerinden birine demir attığı zaman, görevleri gemilerde getirilen malı belirlemek ve sayımını yapmak olan devlet memurları (ümena), bu gemiye çıkarak malları kontrol ederlerdi. Bu kontrolün ardından tüccarlar teftiş yerine götürülürlerdi. Gümrük vergisinin oranı $\% 20$ ile $\% 35$ arasında değişiyordu. Doğu'dan veya Batı'dan gelen Müslüman tüccarlar, Hristiyan tüccarlara göre daha az gümrük vergisi öderlerdi. Avrupalı tüccarlar, gümrük vergisi açısından tek bir muameleye tabi değillerdi. Onlara, getirdikleri mallara göre farklı işlem yapılabiliyordu. Limana getirilen ithal mallar, hemen gümrük binasına taşınır, simsarlar malların fiyatını belirler ve bazen de demir, kereste gibi ihtiyaç duyulan mallara el koyarlardı (Hasan, 1986, s. 79-81).

Fâtımîler, şehirlerde ticaretin daha kolay yapılabilmesi için, güvenliğe de önem vermiştir. Muiz Lidinillah ve ondan sonra gelen Fâtımî halifeleri, Mısır (Fustat, Asker ve Kataî şehirleri), İskenderiye ve Dimyat'taki tersanelerde savaş gemileri inşa ettirmişler bu gemilerden bazıları Askalan, Sur ve Akka gibi liman şehirleri arasında devriye gezerek sınır güvenliğini sağlamışlardır. (Hasan, 1986, s. 111).

Fâtımîler de iki tane önemli iktisadi kurum bulunmaktaydı. Bunlardan birisi "muhtesiplik" diğeri ise "divanüll-mâl"idi.

Muhtesiplik: Sevap anlamına gelen muhtesip, Arapça ihtesebe fiilinden türemiştir. Dinî bir kurum olarak muhtesiplerin görevi, çarşılarda esnaf ve tüccarı kontrol etmek, tartı, ölçü ve fiyatları incelemek, insanların ahlâk ve davranışlarıyla ilgilenmek, ticaret, eğitim, şehircilik gibi konulardaki şikâyetlere bakmak, denetlemek, yasaklamak ve gerektiğinde cezalandırmaktı. Günümüzde belediye bünyesinde bulunan zabitalar gibi görev yapıyorlardı Muhtesibin yardımciları çeşitli meslek grubundan olan arifler ve eminler ile şehirdeki mahallenin başkanlarıydı. Muhtesipler aynı zamanda kadı ile birlikte hareket etmişlerdir. Fâtımîlerde halife veya vezir tarafından şehirlere atanıyorlardı. (Gül, 1997, s. 199; Şeşen, 1987, s. 120-121; Hitti, 2011, s. 1007).

Divanü'l-Mâl: Devletin mali işlerinin yürütüldüğü kurumdur (Gül, 1997: 199).

\section{2) Kudüs Haçıı Krallığı Döneminde íktisadî Yapı:}

1104 ylında Akka'nın Haçlıların eline geçmesinde, Ortaçağ'in en önemli İtalyan ticaret devletlerinden Cenevizlilerin büyük katkıları olmuştur. Baudouin onlara bu hizmetlerin karşıllğı olarak fethedilen şehirlerin üçte biri ile o çevrede eşit oranda toprak vermiştir.. Dolayısıyla Akka limanının gümrük gelirinin üçte biri de Cenevizlilerin olmuştur. Bu Cenevizliler için büyük bir gelir kaynağı demekti. Ayrıca Baudouin, Cenevizlilere krallığın her 
tarafında vergi muafiyeti hakkı tanımıştır. Bunlardan başka, Yafa ve Kudüs şehirlerinde bir mahalle verdiği gibi Akka'da da bir mahallenin kendilerine bırakılacağına dair teminat vermiştir.(Heyd, 1975, s. 150).

Haçlıların Batıdan Yakın Doğu’ya gelişi bölgeye savaş getirmekle birlikte aynı zamanda Mısır, Suriye ve Haçlı devletlerinde tüccarların varlığının artmasına da zemin hazırlamıştır (Constable, 2001, s. 145). Batının tüccar ulusları (Cenevizliler, Venedikliler, Pisalılar ve Marsilyalılar) Kudüs Krallığının deniz limanlarında zamanla koloniler kurmuşlardır. Kudüs Krallığına bağlı Filistin kıyı şehirleri arasında en güvenilir liman olarak da Akka da gerek ticari gerekse stratejik bakımdan önemli bir role sahipti. Haçlılar döneminde Akka'da ticari hayat çok canlı olmuştur. Geniş ve güvenilir limana sahip olan şehir, hacı ve mal taşıyan büyük tonajlı gemilere sürekli olarak ev sahipliği yapardı. Tüccarlar, burada Doğudan gelen malları Avrupa'ya göndermek için birçok firsat bulmuşlardır (Runciman, 1988, s. 6). Tüccarlar, bu dönemde Akka'da dâhil olmak üzere Yakın Doğudaki limanlara sene de iki defa uğrarlardı. Bu seferler genelde Mart-Nisan veya Temmuz-Ağustos aylarında olurdu. Tüccarlar, özellikle kıymetli eşya götürdükleri vakit korsanlara karşı beraberindeki gemilerden başka küçük filolar da yollarlardı. Bu küçük filolardan birinin Doğu limanlarına gelmesi ticari faaliyetin canlanmasında etkin rol oynardı ve filolar limanlarda kaldığı sürece limanlar panayır halini alırdı. Bununla birlikte liman şehirlerinde bulunan çok sayıda batılı tüccarlar da dükkânlarını boş bırakmamaya bakarlar ve bu nedenle dükkânlarını sürekli açık tutarlardı. Batı ile doğu arasındaki bu mübadele bütün yıl sürerdi (Heyd, 1975, s. 196-197). Bu tüccarlar soğuklar yaklaşmadan ülkelerine geri dönerlerdi. Yıl boyunca limanlara çok sayıda gemi yanaşırdı (Abulafia, 2012, s. 334).

Tüccarlar, Avrupa'dan bölgeye gelirken uzun mesafeler katederlerdi. Akdeniz geçilirken pek zorluklarla karşılaşılmazdı. İyi durak noktaları ve rahat merhale sığınakları bulabilmek için, çok gelişmiş olan Avrupa sahilleri izlenir ve adaların birinden öbürüne giderek yol takip edilirdi. Kuzey Denizinden yola koyulmuş olan hacıların ve tüccarların bulundukları gemiler, Cebelitarık Boğazı'nı geçtikten sonra İspanya, Fransa ve İtalya sahilleri boyunca kavis çizerek yola devam ederlerdi. Marsilyalılar da İtalya sahillerinden Sardunya, Sicilya ve Kandiya'ya ardından bazen Rodos ve Kıbrıs'a uğrayarak Yakın Doğu'ya gitmek için doğrudan Akka'ya ulaşırlardı. İyi bir rüzgâr eserse bu geçiş on beş gün ve on beş geceden fazla sürmezdi. XII. yüzyıl boyunca bu yol izlenmiştir (Heyd, 1975, s. 197-198).

Akka, Haçlılar döneminde cam üretimi konusunda kuzeydeki Sur şehrinin ardından ikinci sırada gelmekteydi. Yerli halkın ürettiği camdan yapılmış eşyalar, tüccarlar vasıtasıyla kiliselerde ve evlerde kullanılmak üzere Avrupa'ya taşınmıştır (Hazard, 1977, s. 5). Huzistan, Fergane, Kuzey Afrika ve özellikle Suriye ile birlikte Akka'da da bol miktarda zift bulunurdu (Bakır, 1998, s. 552).

Akka'da, Frank tüccarlarının kurmuş olduğu loncaların yanında, hayatlarını ticaretle kazanan bir sürü Doğulu Yahudi ve Hristiyan'la birlikte Musul'dan tüccarlarda bulunurdu. Akka, bunların yanı sıra Levant ticaretinin de merkezi konumundaydı. Güneydoğu Asya'dan Hint 
Okyanusu kıyılarından Arap tüccarlar tarafından getirilen baharat ve parfüm, Çin'den ipek, İran'dan inci, Orta Asya'dan misk gibi ürünler ilk olarak bölge coğrafyasının merkezi konumundaki Bağdat'ta toplanıyor daha sonra da Levant'taki liman şehirlerine gönderiliyordu. Yine Dımaşk'da ve Halep'te yapılan el dokumaları ve kumaşlar, Avrupa'ya gönderilmek üzere Akka ve Levant’taki diğer liman şehirlerine yollanıyordu. (Tez, 2001, s. 161).

XII. yüzyılda Yakın Doğu'da ticaret, seyahat ve savaş koşullarının değişmesiyle birlikte ticaret şehirlerinde han kavramı da değişmiştir. Müslüman ve Yahudi yolcular, bölgede kendi misafirhanelerinde kalmaya devam ederken, Haçı Seferleri dönemi boyunca Mısır'a, Suriye’ye ve Filistin'e yeni gelen Avrupalı tüccarların konaklama ihtiyaçlarına cevap vermek üzere hanların yeni türleri ortaya çıkmıştır. Bunları şöyle sıralanabilir; 1) Yerleşik Yahudiler ve Müslümanlara yönelik han (the funduq), 2) Müslümanlı̆̆ın hüküm sürdüğü Mısır ve Suriye'deki Hristiyanlara yönelik han (İtalyanca fondaco diye geçer), 3) Haçlı Devletlerindeki Hristiyanlara yönelik olan han (fondaco) (Constable, 2001, s. 148).

1) Yerleşik Yahudiler ve Müslümanlara yönelik han: Bu hanlar, öncellikle Müslüman ve Yahudi tüccarlar için şehir hanı ve bir depo tesisi olarak hizmet vermiştir. Hanlarda, sık sık hayır amaçlı işler yapılmıştır. Bu tip hanlar, tüccarlar ve diğer yolcular için ücretsiz ya da ucuz konaklama imkânı sağlamak için kurulurdu. Genelde bu tür hanlarda konaklama ve depolama için ücret talep edilmiştir. Talep edilen ücretlerden elde edilen gelirler ise camiler, sinagoglar, okullar veya yoksul yardımı gibi hayırlı işlerde harcanırdı.

2) Müslümanlığın hüküm sürdüğü Mısır ve Suriye'deki Hristiyanlara yönelik han: Bu hanlar, Müslüman şehirlerde, özellikle de İskenderiye'de yabancı Hristiyan tüccarların barınmasında kullanılan hanlardır. Her ne kadar birinci tür hanlarla ilişkilendirilse de bu tür hanların kullanım amacı oldukça farklıydı. Bu hanlar genelde yabancı yolculara ev sahipliği yapma ve malların depolanması için güvenli bir yer sağlıyordu. Örneğin Müslüman şehirlerde yaşayan Venedikli veya Cenevizli tüccarların sahibi kendilerinden olan bu hanlarda ikamet etmesi beklenirdi. Bu tür hanlar, ülkelerinden uzakta kendilerini vatandaşları arasında güvende hissedebilecekleri bir sığınak olmuştur. Müslümanlar açısından ise, şehre gelen yabancıların zapt edilebildiği ve mallarının vergilendirilmesi için değerlendirildiği yerlerdir.

3) Haçlı Devletlerindeki Hristiyanlara yönelik olan han: Bu tür hanlar ise Venedik, Ceneviz ve Pisa gibi milletlere verilen ticari imtiyazların bulunduğu hanlardır. Batılı tüccarlar bu hanların ihtiyaçlarını kendilerine göre tasarlamışlardır (Constable, 2001, s. 148-149).

Haçlı şehirlerindeki hanlar, farklı bir yapı ve işleve sahiptir. Akka, Sur ve Antakya'daki hanlar Venedikliler, Cenevizliler ve diğer yabancı topluluklar tarafından ele geçirilen büyükşehir mahallerinde bulunan binalardan ibaretti. Dini ve politik nedenlerden dolayı hanların ölçüleri Mısır'dakiler gibi aynı oranda düzenlenmemiştir. Dışarıdan haçlı şehirlerine gelen tüccarlar, eğer uzun zaman bu bölgede kalacaksa kendileri konut sahibi olma yoluna gitmişlerdir, konut 
sahibi olmayanlar ise genelde kiralamışlardır. Haçlılarda ilk hanlar 1098'de Antakya Prensi Bohemond'un, Cenevizlilere bir kilise, bir kuyu ve otuz komşu ev ile birlikte bir han vermesiyle ortaya çıkmıştır. 1140, 1153, 1167 ve 1183 yıllarında Antakya'da yapılan Venediklilerle olan anlaşmalarda Venediklilere han tahsis edileceği bildirilmiştir. XII. yüzyılın sonlarında ise Pisa'lılar da 1187 ve 1189 yılları arasındaki imtiyazlarla hem Sur'da hem de Akka'da firınlar, banyolar, değirmenler ve evler ile birlikte verilen hanlara sahip olmuşlardır (Constable, 2001, s. 149).

\section{Sonuç}

XI. ve XII. yüzyıllarda Fâtımîler, Selçuklular, Haçlılar ve kısa bir sürede olsa Eyyûbîlerin hâkimiyeti altına giren Akka, iki yüz yıllık bu dönemde hem Müslümanlar hem de Hristiyanlar tarafından yönetilmiştir. Kudüs'e yakınlığından dolayı sahip olduğu stratejik önemi ve ticaret yolları üzerinde bulunması şehrin önemini artırmıştır. Nitekim bu özelliklerinden dolayı şehir, Hristiyan ve Müslümanların hatta Şiî Müslümanlar ile Sünnî Müslümanların dahi karşı karşıya gelmesine neden olmuştur. Fâtımîlerin 969'da ele geçirdiği şehir, yaklaşık bir asır boyunca Fâtımîlerin kontrolü altında kalmıştır. Selçuklu hükümdarı Melikşah döneminde Selçuklulara katılan şehir, I. Haçlı Seferi'nin ardından Haçlıların eline geçmiştir. İki asır boyunca şehrin yönetim bakımından Hristiyan ve Müslüman devletler tarafından arasında el değiştirmesi ve devletler arasındaki verilen mücadeleler, şehre sahip olmanın önemini ortaya koymaktadır. Bununla birlikte özellikle Haçlı Seferleriyle birlikte bölgeye gelen Haçlılar, şehrin deniz kenarında olması nedeniyle ticari faaliyetler konusunda o dönemde son derece önemli mesafe katetmişlerdir. Bunun en güzel örneği Ceneviz ve Venedik gibi ticaret devletlerinin Akka'da ticari faaliyetlerde bulunmasıdır. 1104 yılında Haçlıların ele geçirdiği şehirde, Ceneviz ve Venedik gibi önemli ticaret devletleri, Kudüs Krallığı'nın kurulmasından hemen sonra Akka'da mahallelere sahip olmuşlar ve ticari faaliyetlerini buradan yürütmeye çalışmışlardır. Ayrıca Haçlılar, şehrin Kudüs'e yakın olmasından dolayı Kudüs'e deniz yoluyla gelecek hacıların, Akka limanı aracılığıyla bölgeye gelmesini sağlamışlardır. Bu da bize dini bakımdan şehrin önemli bir özelliğini ortaya koymaktadır. Ticari faaliyetler konusunda şehrin limanının doğu ve batı arasında köprü vazifesi görmesi, şehri ekonomik bakımdan son derece olumlu yönde etkilemiştir. Uzak doğudan getirilen mallar Akka limanı aracılığıyla Avrupa'ya taşınmış bu da ekonominin sürekli canlı kalmasını sağlamıştır. Ticari faaliyetlerle birlikte, hem doğudan hem de batıdan gelen tüccarlar, Akka'da bulunan hanlarda konaklayıp ticaret yapma imkânına kavuşmuştur. Bu da şehri sosyo-ekonomik bakımdan olumlu yönde etkilemiştir. 


\section{Kaynakça}

Abdülaziz ed-Dûrî, (1994). “Divan”, (C. IX, s.377-381), İstanbul: TDV İslam Ansiklopedisi.

Abulafia, D. (1995). Trade and Crusade (1050-1250), New York: Cross Cultural Convergences in the Crusader Period, Edit. Michael Goodich, Peter Lang,

Bakır, A. (1998). Ortaçă̆ islam dünyasında madenler ve maden sanayi. (Belleten, C.LXI), Ankara: TTK.

Cahen, C. (2010). Haçlı seferleri zamanında doğu ve batı, Mustafa Daş (Çev.), İstanbul: Yeditepe.

Constable, O. R. (2001). The crusades from the perspective of Byzatium and the Muslim world: Funduq, Fundaco, Khân in the wake of christian commerce and crusade, Washington: Dumbarton Oaks.

Fayda, M. (1995), “Fey”, (C.XII, s.511-513), İstanbul: TDV İslam Ansiklopedisi.

Gül, M. (1997). XI ve XIII. yüzyıllarda Kudüs, (Yayınlammaış Doktora Tezi), Fırat Üniversitesi, Elazığ.

Harekât, İ. (1992), "Berîd", (C.V, s-498-501), İstanbul: TDV İslam Ansiklopedisi.

Hasan İbrahim, H. (1985) İslam tarihi Abbasilerin ikinci dönemi (232-447/847-1055): (Hamdaniler-Tulunoğulları-İhşidiler-Fâtimiler-Ağlebiler-İdrisiler-Endülüs Emevi DevletiHammudiler), İsmail Yiğit, Sadreddin Gümüş, A. Turan Arslan, Hamdi Aktaş (Çev.), İstanbul: Kayıhan.

Hazard, H. W. (1977). A History of crusade: The art and architecture of the crusader states, Wisconsin: University of Wisconsin.

Heyd, W. (1975). Yakın-doğu ticaret tarihi, Enver Ziya Karal (Çev.), Ankara: TTK.

Hitti, P. (2011). İslam tarihi, Salih Tuğ (Çev.), C.II. İstanbul: Marmara Üniversitesi İlahiyat Vakfi.

Masonluğun Kurucuları: Tapınak Şövalyeleri, https://www.hasankocabas.com.tr/icerik-462tapinak_sovalyeleri_ve_masonluk.html.(Erişim Tarihi: 16.06.2020).

Kedar, B. (1999). On the origins of the earliest laws of frankish jerusalem: The Canons of the council of Nablus, 1120, Speculum (Vol.74, No:2, s. 310-335), Chicago: The University of Chicago Journal.

Köprülü, M. F. (1997). “Âmil”, (C. I. 402-404), İstanbul: MEB İslam Ansiklopedisi.

Le Strange. G. (1890). A description of Syria and the Holy Land: Palestine under the moslems (From A.D. 650 to 1500), Londra: Commitee of The Palestine Exploration Fund by Alexander Watt.

Mardin, E. (1977). “Kadı”, (C.VI, s.42-44), İstanbul: MEB İslam Ansiklopedisi.

Murray, A. V. (1992). The Army of Godfrey of Bouillon, 1096-1099: Structure and Dynamics of A Contingent on The First Crusade, Revue belge de philologie et d'histoire Journal, (C. LXX, s.301-329). 
Nader, M. (2006). Burgesses and Burgess Law in the Latin Kingdom of Jeruselam and Cyprus, New York: Aldershot.

Pringle, D. R. (2002). Haçlı Krallı̆̆ı döneminde Filistin'de Hristiyan nüfus: Kiliselerin tanıklı̆̆l, Muammer Gül (Çev.), S.III. 2002, Şanlıurfa: Harran Üniversitesi İlahiyat Fakültesi.

Runciman, S. (1987). Haçlı seferleri tarihi, Fikret Işıltan (Çev.), C.II. Ankara: TTK.

Sevim, A. (2000). Suriye ve Filistin Selçukluları tarihi, Ankara: TTK.

Şeşen, R. (1987). Selahaddin Eyyûbî ve Devlet, İstanbul: Kelepir.

Tez, Z. (2001). Bilim ve teknikte ortaçağ müslümanları, Ankara: Nobel.

Yılmaz, H. (2016). Fâtımîler ve fâtımî halifeleri, Ankara: Elips.

Zeydan, C. (1965). İslam medeniyeti tarihi, C.I, İstanbul: Üçdal Neşriyat. 